\section{Physical Compatibility of High- Concentration Bupivacaine with Hydromorphone, Morphine, and Fentanyl}

In the field of oncology and in the setting of chronic pain, there are subsets of patients whose pain is refractory to usual drug dosages. Instead, to achieve acceptable pain control, combinations of local anesthetics and narcotics at elevated concentrations are required.

Although there is some literature on the compatibility of various combinations of these drugs, our institution needed data for these more concentrated solutions. To ensure patient safety and to ensure that acceptable expiry data were available, we performed physical compatibility testing for these more highly concentrated solutions.

We conducted a physical compatibility study of the various concentrations of bupivacaine used in the hospital with hydromorphone, morphine, or fentanyl, as listed in Table 1. The solutions were adjusted to volume with normal saline (Baxter Corporation, Mississauga, Ontario; lot W8F25B1, expiry September 2009) and were packaged in either polypropylene syringes (BD, Franklin Lakes, New Jersey; lot 8353527) or nonDEHP (di(2-ethylhexyl) phthalate) bags (Intravia, Baxter

Table 1. pH Range of Bupivacaine Combined with Either Hydromorphone, Morphine, or Fentanyl and Stored at $5^{\circ} \mathrm{C}$ with Protection from Light*

\begin{tabular}{|c|c|c|c|}
\hline $\begin{array}{l}\text { Concentration of } \\
\text { Bupivacaine* }\end{array}$ & $\begin{array}{c}\text { Concentration of } \\
\text { Narcotic }\end{array}$ & Storage Container & $\begin{array}{c}\text { pH Over Study } \\
\text { Periodt }\end{array}$ \\
\hline & Hydromorphone‡ & \multirow{6}{*}{$\begin{array}{l}\text { Polypropylene syringe } \\
\text { Non-DEHP bag } \\
\text { Polypropylene syringe } \\
\text { Non-DEHP bag } \\
\text { Polypropylene syringe } \\
\text { Non-DEHP bag } \\
\text { Polypropylene syringe } \\
\text { Non-DEHP bag } \\
\text { Polypropylene syringe } \\
\text { Non-DEHP bag }\end{array}$} & \multirow{6}{*}{$\begin{array}{l}4.47-4.74 \\
4.56-4.76 \\
4.63-4.82 \\
4.63-4.84 \\
4.62-4.96 \\
4.09-4.88 \\
4.84-5.36 \\
4.54-5.13 \\
4.63-4.82 \\
4.17-4.83\end{array}$} \\
\hline $0.01 \mathrm{mg} / \mathrm{mL}$ & $43.0 \mathrm{mg} / \mathrm{mL}$ & & \\
\hline $20.0 \mathrm{mg} / \mathrm{mL}$ & $25.0 \mathrm{mg} / \mathrm{mL}$ & & \\
\hline $37.5 \mathrm{mg} / \mathrm{mL}$ & $0.01 \mathrm{mg} / \mathrm{mL}$ & & \\
\hline $0.01 \mathrm{mg} / \mathrm{mL}$ & $0.01 \mathrm{mg} / \mathrm{mL}$ & & \\
\hline $20.0 \mathrm{mg} / \mathrm{mL}$ & $0.01 \mathrm{mg} / \mathrm{mL}$ & & \\
\hline & Morphine§ & \multirow{6}{*}{$\begin{array}{l}\text { Polypropylene syringe } \\
\text { Non-DEHP bag } \\
\text { Polypropylene syringe } \\
\text { Non-DEHP bag } \\
\text { Polypropylene syringe } \\
\text { Non-DEHP bag } \\
\text { Polypropylene syringe } \\
\text { Non-DEHP bag } \\
\text { Polypropylene syringe } \\
\text { Non-DEHP bag }\end{array}$} & \multirow{6}{*}{$\begin{array}{l}3.33-3.73 \\
3.32-3.62 \\
3.44-3.76 \\
3.42-3.84 \\
4.64-5.00 \\
3.98-4.72 \\
5.11-6.00 \\
4.50-5.94 \\
4.48-4.97 \\
4.08-4.77\end{array}$} \\
\hline $0.01 \mathrm{mg} / \mathrm{mL}$ & $43.0 \mathrm{mg} / \mathrm{mL}$ & & \\
\hline $20.0 \mathrm{mg} / \mathrm{mL}$ & $25.0 \mathrm{mg} / \mathrm{mL}$ & & \\
\hline $37.5 \mathrm{mg} / \mathrm{mL}$ & $0.01 \mathrm{mg} / \mathrm{mL}$ & & \\
\hline $0.01 \mathrm{mg} / \mathrm{mL}$ & $0.01 \mathrm{mg} / \mathrm{mL}$ & & \\
\hline $20.0 \mathrm{mg} / \mathrm{mL}$ & $0.01 \mathrm{mg} / \mathrm{mL}$ & & \\
\hline $0.01 \mathrm{mg} / \mathrm{mL}$ & $\begin{array}{l}\text { Fentanylๆ } \\
43.0 \mu \mathrm{g} / \mathrm{mL}\end{array}$ & \multirow{5}{*}{$\begin{array}{l}\text { Polypropylene syringe } \\
\text { Non-DEHP bag } \\
\text { Polypropylene syringe } \\
\text { Non-DEHP bag } \\
\text { Polypropylene syringe } \\
\text { Non-DEHP bag } \\
\text { Polypropylene syringe } \\
\text { Non-DEHP bag } \\
\text { Polypropylene syringe } \\
\text { Non-DEHP bag }\end{array}$} & \multirow{5}{*}{$\begin{array}{l}4.37-4.69 \\
4.14-4.50 \\
4.45-4.62 \\
3.96-4.58 \\
4.63-5.00 \\
4.07-4.70 \\
5.31-5.83 \\
4.54-5.60 \\
4.73-5.27 \\
4.01-4.86\end{array}$} \\
\hline $20.0 \mathrm{mg} / \mathrm{mL}$ & $25.0 \mu \mathrm{g} / \mathrm{mL}$ & & \\
\hline $37.5 \mathrm{mg} / \mathrm{mL}$ & $0.15 \mu \mathrm{g} / \mathrm{mL}$ & & \\
\hline $0.01 \mathrm{mg} / \mathrm{mL}$ & $0.15 \mu \mathrm{g} / \mathrm{mL}$ & & \\
\hline $20.0 \mathrm{mg} / \mathrm{mL}$ & $0.15 \mu \mathrm{g} / \mathrm{mL}$ & & \\
\hline
\end{tabular}

$\mathrm{DEHP}=$ di(2-ethylhexyl) phthalate.

*Bupivacaine 0.75\% (Hospira Healthcare Corporation, Saint-Laurent, Quebec; lot 63405DD, expiry March 1, 2010) or 4\% (The Ottawa Hospital, Ottawa, Ontario; lot 080806, expiry August 6, 2009). tRange of $\mathrm{pH}$, as measured on days $0,7,14,21$, and 28.

¥Hydromorphone $2 \mathrm{mg} / \mathrm{mL}$ (Sandoz Canada Inc, Boucherville, Quebec; lot 146791, expiry April 2011) or $50 \mathrm{mg} / \mathrm{mL}$ (Sandoz Canada Inc; lot 141131, expiry July 2009).

§Morphine $2 \mathrm{mg} / \mathrm{mL}$ (Sandoz Canada Inc; lot 143054, expiry April 2009) or $50 \mathrm{mg} / \mathrm{mL}$ (Sandoz

Canada Inc; lot 143179, expiry May 2009; lot 143162, expiry May 2009).

IFentanyl 50 mg/mL (Sandoz Canada Inc; lot 145704, expiry March 2011). 
Healthcare Corporation, Deerfield, Illinois; lot UR09D07248), which were stored at $5^{\circ} \mathrm{C}$ for 28 days with protection from light. Samples ( $5 \mathrm{~mL}$ each) collected on the day of preparation (day 0 ) and on days $7,14,21$, and 28 days after preparation were transferred into clear glass test tubes. The samples were inspected for the presence of precipitate and any change in colour, and the $\mathrm{pH}$ was measured with a calibrated $\mathrm{pH}$ meter (Accumet 25, Fisher Scientific Inc, Nepean, Ontario).

To achieve the higher concentrations of bupivacaine (i.e., 20.0 and $37.5 \mathrm{mg} / \mathrm{mL}$ ), a $4 \%$ solution, compounded in our Pharmacy Department, was used. The $4 \%$ solution is used in the hospital's Pain Clinic for patients whose pain cannot be managed at lower concentrations.

All solutions packaged in either polypropylene syringes or non-DHEP bags remained clear and colourless throughout the course of the study. The $\mathrm{pH}$ of the solutions changed only slightly during the study, with a general trend toward becoming more acidic (Table 1).

Previous studies ${ }^{1-7}$ investigated the chemical stability and/or physical compatibility of various concentrations of bupivacaine and one of the narcotics at lower concentrations in minibags and found them to be stable for at least $72 \mathrm{~h}$ at various temperatures. The chemical stability and/or physical compatibility of the lower concentrations of mixtures stored in syringes was also studied ${ }^{28-10}$; these mixtures were stable for at least 30 days at either room temperature or under refrigeration.

The compounded $4 \%$ solution of bupivacaine was needed to prepare the more concentrated solutions used in this study. Use of this solution might have caused a problem because the solution is at its saturation point for the drug at room temperature, and storage at $5^{\circ} \mathrm{C}$ might have caused precipitation. In this study, storage of solutions at $5^{\circ} \mathrm{C}$ represented a worst-case scenario. Barring future studies generating contrary information, mixtures stored at either $22^{\circ} \mathrm{C}$ or $37^{\circ} \mathrm{C}$ should also be considered physically compatible in either type of packaging (syringe or bag).

In conclusion, all solutions studied and packaged in either polypropylene syringes or non-DHEP bags were physically compatible for 28 days when stored at $5^{\circ} \mathrm{C}$ with protection from light.

\footnotetext{
References

1. Christen C, Johnson CE, Walters JR. Stability of bupivacaine hydrochloride and hydromorphone hydrochloride during simulated epidural coadministration. Am J Health Syst Pharm 1996;53(2):170-173.

2. Nitescu P, Hultman E, Appelgren L, Linder LE, Curalaru I. Bacteriology, drug stability and exchange of percutaneous delivery systems and antibacterial filters in long-term intrathecal infusion of opioid drugs and bupivacaine in "refractory" pain. Clin J Pain 1992;8(4):324-337.

3. Johnson CE, Christen C, Perez MM, Ma M. Compatibility of bupivacaine hydrochloride and morphine sulfate. Am J Health Syst Pharm 1997;54(1): 61-64.

4. Dawson PJ, Bjorksten AR, Duncan IP, Barnes RK, Beemer GH. Stability of fentanyl, bupivacaine and adrenaline solutions for extradural infusion. Br J Anaesth 1992;68(4):414-417.

5. Sattler A, Jage J, Krämer I. Physico-chemical stability of infusion solutions for epiudural administration containing fentanyl and bupivacaine or lidocaine. Pharmazie 1998;53(6):386-391.

6. Tu YH, Stiles ML, Allen LV Jr. Stability of fentanyl citrate and bupivacaine hydrochloride in portable pump reservoirs. Am J Hosp Pharm 1990;47(9):2037-2040.

7. Jage J, Krämer I, Sattler A, Faust P, Dick W. [Postoperative epidural analgesia with bupivacaine- $\mathrm{HCl} 0.06 \% /$ fentanyl $0.0002 \%$. Experiences and physicochemical stability in infusion bags.] Schmerz 1997;11(3):185189. German.

8. Neels JT. Compatibility of bupivacaine hydrochloride with hydromorphone hydrochloride or morphine sulfate. Am J Hosp Pharm 1992;49(9):2149.
}

9. Trissel LA, Xu QA, Pham L. Physical and chemical stability of low and high concentrations of morphine sulfate with bupivacaine hydrochloride packaged in plastic syringes. Int J Pharm Compd 2002;6(1):70-73.

10. Jappinen A, Kokki H, Naaranlahti T. pH stability of injectable fentanyl, bupivacaine, or clonidine solution or a ternary mixture in $0.9 \%$ sodium chloride in two types of polypropylene syringes. Int J Pharm Compd 2002;6(6):471-474.

Ronald F Donnelly, MSc(Chem), BSc(Pharm)

Keith Wong

Jennifer Spencer, BSC, BSc(Pharm), BCOP

Department of Pharmacy

The Ottawa Hospital

Ottawa, Ontario

At the time of the study, Keith Wong was a third-year student in the Leslie Dan Faculty of Pharmacy, University of Toronto, Toronto, Ontario, and was working in the Pharmacy Department of The Ottawa Hospital as a summer student.

\section{Are the Results of the RE-LY Trial Reliable?}

Dabigatran is an oral thrombin inhibitor that is indicated in Canada for the prevention of venous thromboembolism in patients who have undergone hip or knee replacement. ${ }^{1}$ In the RE-LY study (Randomized Evaluation of Long-term anticoagulant therapY), a 2-year multicentre non-inferiority trial, patients with atrial fibrillation who had an increased risk of stroke were randomly assigned (by allocation concealment) to receive dabigatran $110 \mathrm{mg}$ twice daily or $150 \mathrm{mg}$ twice daily (blinded) or warfarin (open-label). ${ }^{2}$ Concomitant use of acetylsalicylic acid (ASA, less than $100 \mathrm{mg} / \mathrm{day}$ ) and amiodarone was allowed. In addition, use of quinidine was permitted until 2 years after the trial started; at that point, the protocol was amended to limit use of this drug because of its ability to increase plasma concentrations of dabigatran. ${ }^{1,2}$

The authors of the RE-LY trial claimed that dabigatran was superior to warfarin at a dose of $150 \mathrm{mg}$ twice daily with respect to preventing stroke and systemic embolism. ${ }^{2}$ In addition, both the $110-\mathrm{mg}$ and $150-\mathrm{mg}$ doses were reported to be superior to warfarin with respect to the rate of hemorrhagic stroke. ${ }^{2}$ However, we have been unable to confirm the authors' conclusions because of flaws in the reported data and inadequacies in the reported components of the study.

The net clinical benefit (outcome) chosen for this trial, a composite of stroke, systemic embolism, pulmonary embolism, myocardial infarction, death, and major bleeding, encompasses problems typically seen with this class of medications, not those that are rare or yet to be discovered. Total serious adverse events were not reported, so the net effect of dabigatran cannot be assessed with certainty, especially given that there was a signal for increased risk of myocardial infarction relative to warfarin., ${ }^{2,3}$ Furthermore, although dabigatran $150 \mathrm{mg}$ twice daily appears to be non-inferior to warfarin with respect to major bleeding, this dose of the drug is associated with a statistically significant increase in the risk of life-threatening or non-life-threatening gastrointestinal bleeding relative to warfarin. ${ }^{2}$ The choice of the patient population is questionable, given the authors' report that nearly 6000 of the 18113 patients in the study had a CHADS(2) score of 0 or $1 . \operatorname{CHADS}(2)$ is a risk stratification index describing the correlation between 5 known risk factors (congestive heart failure, 